Acta vet. scand. 1961, 2, 210-213.

From the State Veterinary Institute of Virus Research, Lindholm, Kalvehave, and the Department of Obstetrics and Gynaecology, The Royal Veterinary and Agricultural College, Copenhagen.

\title{
ON THE SURVIVAL OF FOOT AND MOUTH DISEASE VIRUS IN FROZEN BOVINE SEMEN
}

\section{By}

\author{
B. Chr. H. Gierlфff and Kj. Friis Jakobsen
}

The introduction of a method for freezing bull spermatozoa (Smith \& Polge, 1950) led to better possibilities of international exchange of bovine semen. However, these possibilities may also increase the risk of spreading infectious cattle diseases. In recent years, investigations have been conducted in order to ascertain the resistance to the freezing procedure of a number of infectious agents demonstrated in bull semen. Macpherson \& Fish (1954) found that Brucella abortus, Corynebact. pyogenes, Listeria monocytogenes and Vibrio fetus can survive this procedure. Blackshaw $\&$ Beattie (1955) made the same observation with Trichomonas fetus. Among other infectious agents which may be found in bull semen foot and mouth disease virus (FMD) is of particular interest. Grunnet (1950) showed that during FMD virus is admixed to the semen during the first days of the disease (the generalization stage). To our knowledge no reports have been published on the survival of FMD virus in frozen semen. This report deals with the resistance of FMD virus admixed to diluted bovine semen and then frozen, and the survival of the virus after storage of the semen for one month at $-79^{\circ} \mathrm{C}$.

\section{MATERIAL AND METHOD}

Virus. The virulent material was cattle aphthae (type $\mathrm{O}_{2}$ ) which after comminution with scissors was ground with sterile quartz sand in a mortar and suspended $1: 10$ in a medium, modified according to Baker (Willems \& Leunen, 1957). The suspension was centrifuged for 10 minutes at 3.500 r.p.m., and after careful decantation the supernatant was used as basic material. 
Mice. The technique of Skinner (1953) was applied for titration and demonstration of virus. White baby mice only $2-3$ days old were used, because mice of this age have proved particularly susceptible to infection with FMD virus (Gierløff, 1960). The mortality of the inoculated mice $\left(\mathrm{MLD}_{50}\right)$ was estimated according to Reed \& Muench (1938). The dead mice were examined for contents of FMD virus by the complement fixation test.

Semen. Two ejaculates were collected by means of the artificial vagina. Immediately after collection the ejaculates were diluted $1: 10$ at $30^{\circ} \mathrm{C}$ with a diluent consisting of three parts of 3,2 per cent sodium citrate dihydrate solution, and one part of egg yolk. $2000 \mu \mathrm{g}$ of dihydrostreptomycin was added per cc. of diluted semen. Within the following two hours the diluted semen was cooled in a water bath to $4^{\circ} \mathrm{C}$. Eight hours after the collection, the diluted semen was divided into four portions: $A, B, C$ and D. Basic material of virus was added to the portions $B, C$, and $D$ and all the four portions were diluted $1: 1$ at $4^{\circ} \mathrm{C}$ with a second diluent, which consisted of the yolk citrate diluent and 15 per cent glycerol bidestillate. In the two experiments, carried out at an interval of one month, the diluted semen contained the following approximate amounts of virus:
A Control
B "Highly-infected"
C "Medium-infected"
D "Low-infected"

1st experiment

0

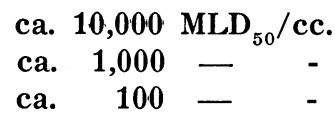

2nd experiment 0

ca. $1,000 \mathrm{MLD}_{50} / \mathrm{cc}$. ca. $100-$ -

The diluted semen was equilibrated overnight (ca. 12 hours) at $4^{\circ} \mathrm{C}$ and the basic material of virus was kept for the same period at $4^{\circ} \mathrm{C}$. Samples of portions A, B, C and D were inoculated intraperitoneally into $8,16,16$ and 16 mice, respectively. At the same time basic material of virus was diluted from $10^{-2}$ to $10^{-8}$ with Baker's medium, and each of these dilutions were inoculated into 8 mice.

The remaining amounts of the portions $\mathrm{A}, \mathrm{B}, \mathrm{C}$ and $\mathrm{D}$ and the basic material of virus were dispensed into 1 cc. glass ampoules and frozen in an alcohol bath at the following cooling rates: $1^{\circ}$ per minute from $4^{\circ} \mathrm{C}$ to $-10^{\circ} \mathrm{C}, 4^{\circ} \mathrm{C}$ per minute from $-10^{\circ} \mathrm{C}$ to $-25^{\circ} \mathrm{C}$, and then as fast as possible to $-79^{\circ} \mathrm{C}$.

Immediately after freezing to $-79^{\circ} \mathrm{C}$ samples from each of the portions $\mathrm{A}, \mathrm{B}, \mathrm{C}$ and $\mathrm{D}$ were thawed in a water bath at $20^{\circ} \mathrm{C}$. Inoculation into mice was performed as before the freezing. 
This procedure was repeated after 24 hours and after one month's storage of the frozen semen at $-79^{\circ} \mathrm{C}$.

\section{RESULTS}

The results from the two experiments are recorded in Table 1. FMD virus was demonstrated in 17 out of the 18 frozen portions

Table 1.

Results found by inoculation into mice of frozen bull semen containing FMD virus.

\begin{tabular}{|c|c|c|c|c|c|}
\hline \multirow[b]{2}{*}{$\begin{array}{l}\text { Exp. } \\
\text { no. }\end{array}$} & \multirow[b]{2}{*}{$\begin{array}{l}\text { Virus-conc.: } \\
\text { MLD } 50 / \text { cc. } \\
\text { dilut. semen }\end{array}$} & \multicolumn{4}{|c|}{ mice dead after inoculation, $\%$ of deaths } \\
\hline & & $\begin{array}{l}\text { before } \\
\text { freezing }\end{array}$ & $\begin{array}{c}\text { immediately } \\
\text { after } \\
\text { freezing }\end{array}$ & $\begin{array}{l}24 \text { hours } \\
\text { after } \\
\text { freezing }\end{array}$ & $\begin{array}{l}1 \text { month } \\
\text { after } \\
\text { freezing }\end{array}$ \\
\hline
\end{tabular}

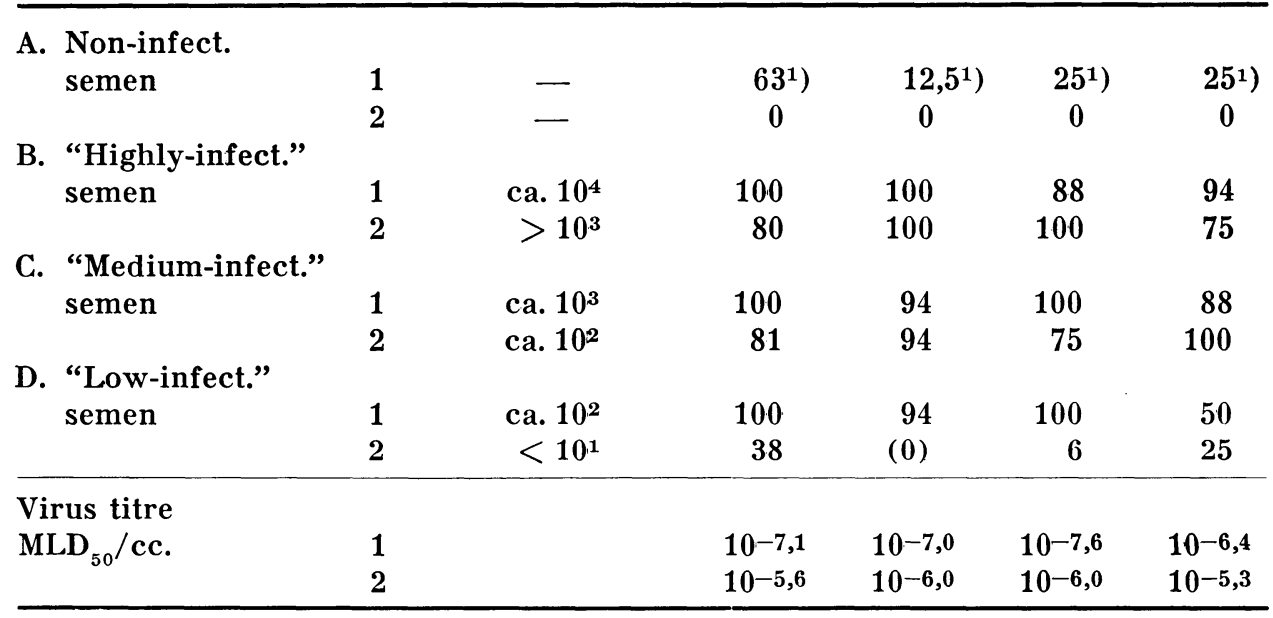

1) FMD virus not demonstrated (cf. text).

() This portion $(\mathrm{D}, 2)$ was only inoculated on 8 unweaned mice, of which the dam ate 2 on the 2nd and 3rd day after injection respectively.

of semen (B, C and D), admixed with virus before equilibration and freezing. Less than $10 \mathrm{MLD}_{50} / \mathrm{cc}$. of FMD virus was added to the one portion (D exp. 2), which did not take on mice when inoculated immediately after freezing. Among the control groups deaths from unknown causes occurred in one group (A exp. 1). However, by inoculation into mice with tissue material from these dead mice and by complement fixation test, FMD virus could not be demonstrated.

Although the results of this study are based only on few observations, they show that FMD virus in bull semen does not 
loose its infectivity by freezing of the semen as described. Nor does storage of the frozen, infective semen for as long as one month influence the survival of the virus. A FMD virus with the titres $\left(\mathrm{MLD}_{50} / \mathrm{cc}\right.$.) given in the table will be completely virulent for cattle.

Acknowledgement. We wish to acknowledge with thanks the help and advice given us by Director, dr. E. Michelsen and Professor N. O. Rasbech.

\section{REFERENCES}

Blackshaw, A. W. \& H. E. R. Beattie: Aust. vet. J. 1955, 31, 214.

Gierlфff, B. C. H.: In press.

Grunnet, N. T.: Dansk Maanedsskr. Dyrlæg. 1950, 61, 167.

Macpherson, J. W. \& N. A. Fish: Amer. J. vet. Res., 1954, 15, 548.

Reed, L. J. \& H. Muench: Amer. J. Hyg., 1938, $27,493$.

Skinner, H. H.: XV. Int. Vet.-Congr., Stockholm, 1953.

Smith, A. U. \& C. Polge: Vet. Rec. 1950, 62, 115.

Willems, R. \& J. Leunen: Methods of Typing and Cultivation of Footand-Mouth Disease Viruses. Project no 208, O.E.E.C., 1957.

\section{SUMMARY}

Bull semen, to which small quantities of FMD virus were added, was frozen and kept one month at $-79^{\circ} \mathrm{C}$. By inoculation into mice it was demonstrated that FMD virus in bull semen had survived the freezing procedure.

\section{ZUSAMMENFASSUNG \\ Uber die Uberlebungsfähigkeit der Maul- und Klauenseuche Virus in tiefgekühltem Bullensamen.}

Bullensamen mit kleinen Mengen von Maul und Klauenseuche Virus gemischt, wurde eingefroren und für einen Monat bei $-79^{\circ} \mathrm{C}$ aufbewahrt. Es wurde demonstriert durch Inokulation auf Mäusen dass die Virus die Tiefkühlungsverfahren des Bullensamens überlebt hatte.

\section{SAMMENDRAG}

Om mund- og klovsygevirus' overlevningsevne $i$ dybfrossen tyresæd.

Tyresæd, hvortil der var tilsat små mængder mund- og klovsygevirus, blev dybfrosset og opbevaret ved $-79^{\circ} \mathrm{C}$ i en måned. Ved inokulation på mus blev det påvist, at virus havde overlevet dybfrysningsproceduren.

(Received January 27. 1961). 